\title{
Serological differences among isolates of viral haemorrhagic septicaemia virus detected by neutralizing monoclonal and polyclonal antibodies
}

\author{
N. J. Olesen, N. Lorenzen, P. E. V. Jørgensen \\ National Veterinary Laboratory, Hangøvej 2, DK-8200 Århus N, Denmark
}

\begin{abstract}
The serological variation among 127 isolates of viral haemorrhagic septicaemia virus (VHSV) was examined by plaque neutralization tests (PNT) using a panel of 4 neutralizing monoclonal antibodies (MAbs) and 1 neutralizing rabbit antiserum (PAb). Three distinct neutralization patterns were observed. All isolates in the largest group (I) were neutralized at high titres by the MAbs and the PA.b. This group included isolates representing the previously described 'Serotypes' 1 and 2. The isolates in Group II were efficiently neutralized by 1 of the MAbs and the PAb but not, unless at low titres, by the remaining $3 \mathrm{MAbs}$. Isolates represented by previously described 'serotype' 3 were in this group. The isolates in Group III were not neutralized at all by any of the MAbs and not, or only moderately, neutralized by the PA.b. Isolates with this reaction pattern have become the most frequent ones from VHS outbreaks in Denmark in recent years. Pronounced crossreaction between Groups I, II \& III in Western blotting using polyclonal rabbit antibodies combined with the ability of 1 antiserum to neutralize 120 out of the 127 isolates indicate that the polyclonal antibodies used define only 1 serotype of VHSV. Groups I to III should be regarded as subtypes. The present panel of antibodies did not allow a distinction between pathogenic and nonpathogenic isolates. No relationship was observed between host species and the reaction pattern as all 3 reaction patterns were present among the 5 isolates originating from fish species other than rainbow trout Oncorhynchus mykiss.
\end{abstract}

\section{INTRODUCTION}

Viral haemorrhagic septicaemia (VHS) is the most serious viral disease affecting the production of rainbow trout Oncorhynchus mykiss in Europe. The causative agent, viral haemorrhagic septicaemia virus (VHSV) or Egtved virus (Jensen 1965), is a member of the Lyssavirus genus of the family Rhabdoviridae (McAllister \& Wagner 1975). The reference strain F1, isolated from rainbow trout in Denmark by Jensen in 1962 was the first isolate of the virus (Jensen 1965).

Three 'serotypes' of VHSV have been described: Type 1, represented by Strain F1; Type 2, represented by the Hededam isolate, both isolated from Danish rainbow trout (Jørgensen 1972, 1980), and Type 3, represented by the French strain $23 / 75$ isolated from brown trout Salmo trutta fario by Kinkelin \& Le Berre (1977). These 'serotypes' were defined by means of dif- ferent versions of the neutralization test; however, in spite of the existence of serological differences, most polyclonal antisera made against Strain F1 crossreacted strongly with the other type strains in $50 \%$ plaque neutralization tests (PNT) (Jørgensen 1974 , 1980, this study), immunofluorescence (IF) assays (Jørgensen 1972, Meier \& Jørgensen 1980), enzymelinked immunosorbent assays (ELISA) (Sanz \& Coll 1992) and Western blotting analyses (this study).

More recently, isolates of VHSV which are not identifiable by neutralization tests but which react by means of IF have been described (Ahne et al. 1986), and such isolates have appeared with increasing frequency in Denmark over the last few years.

The present work was performed to determine if an improved picture of the serological variation among isolates of VHSV could be obtained by PNT using a panel of 4 neutralizing monoclonal antibodies (MAbs) 
and 1 neutralizing polyclonal antiserum (PAb) of rabbit origin. A total of 127 VHSV isolates were examined, including isolates of the virus which had not reacted with the antiserum to Strain F1 used in routine neutralization tests, as well as a number of isolates from fish other than rainbow trout.

\section{MATERIALS AND METHODS}

Cells and virus. Epithelioma papulosum cyprini (EPC) (Fijan et al. 1983) and bluegill fry (BF-2) (Wolf et al. 1966) cell lines were grown in Eagles MEM supplemented with $10 \%$ foetal bovine serum, Tris buffer and antibiotics in standard concentrations. Among 127 virus isolates examined, 117 were of Danish origin, isolated during the previous $30 \mathrm{yr}$ at the National Veterinary Laboratory (NVL), with the exception of the isolate from Atlantic cod Gadus morhua (Jensen et al. 1979, Jorgensen \& Olesen 1987) which was received from Dr S. Mellergård, Danish Institute for Fisheries and Marine Research, Copenhagen, Denmark. One isolate, DK-87, although isolated at NVL, originated from brown trout received in 1969 from Dr P. Ghittino, Instituto Zooprofilattico, Turin (Jørgensen 1980). The isolates were selected to ensure diversity in terms of efficiency of neutralization by a reference rabbit antiserum to the F1 strain, geographic location, host species, and year of isolation.

The Danish isolates except for the Atlantic cod isolate originated from 69 freshwater and 12 seawater farms producing rainbow trout or, in a few cases, brown trout. Isolates from farms on all Danish streams where VHS had occurred during the last 5 yr $(22$ streams) and from all new VHS outbreaks in the period from 1 January 1991 to 1 June 1992 (34 isolates) were included among the samples. Among the Danish isolates were the type strains F. (Jensen 1965) and $\mathrm{He}$ (isolate DK-61) (Jørgensen 1972). One isolate from brown trout, 23/75, representing Type 3, was received from Dr P. de Kinkelin. Institut National de la Recherche Agronomique, Paris, France. Six isolates were received from Prof $W$. Ahne, University of Munich, including isolates 49/82 and 67/82 (Ahne et al. 1986) as well as a VHSV isolate from turbot Scophthalmus maximus (Schlotfeldt et al. 1991) Two isolates, one from chinook salmon Oncorhynchus tshawytscha, obtained by K. Hopper (KHV) (Hopper 1989) and one from coho salmon Oncorhynchus kjsutch, obtained by R. Brunson (RBV) (Brunson et al. 1989), were received from $\mathrm{Dr} J$. Winton, National Fisheries Research Center, Seattle, USA. One isolate, L59x from eel Anguilla anguilla (Castric et al. 1992), was received from Dr $J$ Castric, Laboratoire de Pathologie des Animaux Aquatiques, Brest, France. All isolates were of salmonid origin except for the 3 isolates from cod, eel, and turbot. Apart from certain passage levels of $\mathrm{F} 1$, He and the eel virus, the isolates were not cloned before the study. All isolates were passed at least once in both BF-2 and EPC cell lines prior to use. Prior to neutralization, the isolates were plaque-titrated in microplates with EPC cells using overlay medium containing $0.5 \%$ methyl cellulose.

Antibodies. Development of mouse hybridoma cell lines producing VHSV-neutralizing MAbs has been described (Lorenzen et al. 1990). Each MAb was quantified by means of a sandwich ELISA (Lorenzen et al. 1988) and the IgG concentration adjusted to approximately $5 \mu \mathrm{g} \mathrm{ml} \mathrm{ml}^{-1}$. Neutralizing rabbit antisera to VHSV Strain F1 were prepared using pelleted virus (K697-2) as described by Jørgensen (1974) or gradient purified virus (K59) as described by Olesen et al. (1991a). The sera were treated for 30 min at $56^{\circ} \mathrm{C}$ before use. A panel of neutralizing reagents containing the polyclonal rabbit antiserum K697-2 and the MAbs 3F1H10, 3F2D4, 3F5A1 \& 3F3B4 was assembled. The MAb $3 F 1 H 10$ was identical to MAb I previously described by Lorenzen et al. (1990), MAb 3F2D4 belonged to the IgG2b subclass, and MAbs 3F5A1 \& 3F3B4 belonged to the IgG1 subclass.

Rabbit antiserum to the Coleman strain of infectious hematopoietic necrosis virus (IHNV) was prepared as described for VHSV (Olesen et al. 1991a).

$50 \%$ plaque neutralization test (PNT). All virus isolates were examined by PNT using the panel of 5 neutralizing reagents. The test was performed as described by Olesen \& Jørgensen (1986) except that the complement was omitted. Briefly, 8 successive 2-fold dilutions of antibody, starting at 1:20, were mixed in round bottom, 96-wel.1 microplates with equal volumes of virus suspension adjusted to contain approximately 40 plaque-forming units (PFU) per inoculum. Each antibody-virus mixture was incubated for $1 \mathrm{~h}$ at $15^{\circ} \mathrm{C}$ and then added to 2 replicate wells $(10 \mu \mathrm{l}$ well-1) containing monolayer cultures of EPC cells in 96 -well microplates (Nunc, Denmark). After adsorption for $1 \mathrm{~h}$ at $15^{\circ} \mathrm{C}$ the cell cultures were overlaid with medium containing $0.5 \%$ methyl cellulose and incubated for $5 \mathrm{~d}$ at $15^{\circ} \mathrm{C}$ followed by fixation and staining The PNT titre is expressed as the reciprocal value of the highest antibody dilution causing $50 \%$ reduction of the average number of plaques when compared to cultures inoculated with normal rabbit serum and virus.

Immunofluorescence (IF) assay. Indirect immunofluorescence assay on virus infected EPC cell cultures was performed as described by Lorenzen et al. (1988) using monoclonal or polyclonal antibodies.

Double-sandwich enzyme-linked immunosorbent assay (ELISA). The reactivity of selected isolates among the VHSV samples was evaluated by double- 
sandwich ELISA using protein-A purified Ig from rabbit antiserum against VHSV Strain F1 (K59) and IHNV Coleman strain (K2702) as catching antibody and horseradish peroxidase (HRP) conjugated Ig from the same antisera as detecting antibody, as described by Olesen \& Jørgensen (1991).

Competitive ELISA. The relationship among the epitopes recognized by each of the 4 neutralizing MAbs was examined by a competitive ELISA as described by Lorenzen et al. (1988). Microtitre wells were first coated with purified VHSV (Strain F.1) at approximately $15 \mathrm{ng}$ virus well ${ }^{-1}$ The second layer was either buffer without MAb or MAbs adjusted to $5 \mu \mathrm{g} \mathrm{Ig} \mathrm{ml}{ }^{-1}$, $50 \mu \mathrm{l}$ well ${ }^{-1}$. After a $1 \mathrm{~h}$ incubation, $10 \mu \mathrm{l}$ of biotinylated MAb (25 $\left.\mathrm{mg} \mathrm{Ig} \mathrm{ml}^{-1}\right)$, were added to the wells and incubation continued for another hour. After washing, the reaction was visualized with HRP conjugated to streptavidin followed by addition of. $\mathrm{H}_{2} \mathrm{O}_{2}$-orthophenylenediamine substrate. The colour reaction obtained with buffer followed by biotinylated MAb in the second layer was described as $100 \%$ reactivity for each of the biotinylated MAbs. The results were expressed as the percent reactivity left after incubation with non-biotinylated MAbs (Lorenzen et al. 1988). The G-specific, non-neutralizing MAb IP1H3 was included to illustrate the reactivity with a non-competing MAb (Lorenzen et al. 1990). Reduction of reactivities to $25 \%$ or less of controls was taken as an indication that the 2 competing MAbs reacted with the same (or very closely related) epitope whereas reactivities above $75 \%$ indicated that the epitopes were not related.

Immunoblotting. Seven selected VHSV isolates were propagated in BF-2 cells, purified on sucrose gradients, and examined by immunoblotting as described by Lorenzen et al. (1990) using rabbit antiserum K59 made against VHSV Strain F1. Total protein staining of blotting membranes was performed with colloidal gold (Moremans et al. 1985). Immunoblots using MAbs were performed with and without disruption of disulphide bonds of VHSV polypeptides as described by Lorenzen et al. (1990)

Table 1. Competitive binding studies of 4 neutralizing MAbs and 1 non-neutralizing G-reactive MAb. Results are expressed as percent reactivity remaining after inhibition by competitive $M A b$ compared with reactivity of the MA.b with buffer alone

\begin{tabular}{|lrrrrr|}
\hline \multirow{2}{*}{$\begin{array}{l}\text { Competitive } \\
\text { MAb }\end{array}$} & 3F1H10 & 3F2D4 & 3F5A1 & 3F3B4 & IPIH3 \\
\hline 3F1H10 & 10 & 16 & 22 & 9 & 82 \\
3F2D4 & 6 & 9 & 17 & 5 & 90 \\
3F5A1 & 4 & 6 & 10 & 3 & 80 \\
3F3B4 & 10 & 16 & 21 & 8 & 84 \\
IP1H3 & 85 & 91 & 78 & 80 & 20 \\
Buffer & 100 & 100 & 100 & 100 & 100 \\
\hline
\end{tabular}

\section{RESULTS}

\section{Characterization of MAbs}

Immunoblots revealed that all 4 MAbs in the panel were directed against the viral glycoprotein (G) and that they were able to bind only to the non-reduced form of the G protein. By IF, all 4 MAbs stained antigen localized in the presumed Golgi zone of infected cells (not illustrated). The $4 \mathrm{MAbs}$ thus showed the same reaction pattern as that of MAb l (identical with MAb 3 F1H10) described by Lorenzen et al. (1990). Against VHSV Strain F1 (8th cell-culture passage) the PNT titre of each of the 4 MAbs was 2560.

Competitive binding studies by means of ELISA indicated that the 4 neutralizing MAbs were all directed to the same epitope or to closely related epitopes, as the reactivity of each $M A b$ was reciprocally reduced to less than $25 \%$ by each of the other 3 neutralizing MAbs. The G-specific non-neutralizing MAb IP1H3, however, was directed to an epitope different from that recognized by the neutralizing MAbs (Table 1)

\section{Neutralization patterns}

When the 127 isolates of VHSV were reacted with each of the 5 neutralizing reagents, 3 different neutralization patterns were observed. These patterns formed groups that were based upon the relative efficiency of neutralization rather than on the exact titres. The largest group (Reaction Pattern I), included 55 of the 127 isolates tested. These isolates were effectively neutralized by all 4 MAbs and by the rabbit antiserum, with median titres of 2560 (Table 2). Strains F1 \& He, representing the previous 'Serotypes' 1 \& 2, respectively, were in this group which also contained the 3 isolates known to be non-pathogenic for rainbow trout, i.e. the 2 North American isolates KHV and RBV (Dr J. Winton pers. comm., and pers obs.) and the isolate from cod (pers. obs.). Two isolates from brown trout, DK-87 \& DK-566, as well as isolate DK-29, pathogenic for brown trout (Jørgensen 1980), also belonged to this group.

Reaction Pattern II contained isolates which were well neutralized by the rabbit antiserum (median titre 5120) and by the MAb 3F5A1 (median titre 640) but not neutralized or neutralized at low titres by the MAbs $3 \mathrm{~F} 1 \mathrm{H} 10$, 3F2D4 \& 3F3B4, median titres being $<40$ with 320 as the highest titre (Table 2). Twenty-four $(19 \%)$ isolates belonged to this group including the previously described 'Serotype' 3 isolate, 23/75, from brown trout and L59x' from elvers. Isolates belonging to Group II were 
Table 2. Median and range of neutralization titres in each of 3 reaction pattern groups with 4 monoclonal antibodies (MAb) and 1 rabbit antiserum (PAb) in plaque neutralization tests against 127 VHSV isolates. Median titres: $50 \%$ fractile. Range of titres: highest and lowest neutralization titre in each group

\begin{tabular}{|c|c|c|c|c|c|}
\hline Reaction pattern: & MAb 3FIH10 & MAb 3F2D4 & MAb 3F5A1 & MAb 3F3B4 & PAb 697-2 \\
\hline \multicolumn{6}{|l|}{ Median titres } \\
\hline I & 2560 & 2560 & 2560 & 2560 & 2560 \\
\hline II & $<40$ & $<40$ & 640 & $<40$ & 5120 \\
\hline III & $<40$ & $<40$ & $<40$ & $<40$ & 640 \\
\hline \multicolumn{6}{|l|}{ Range of titres } \\
\hline I & $320-\geq 5120$ & $160-\geq 5120$ & $320-\geq 5120$ & $320-\geq 5120$ & $320-\geq 5120$ \\
\hline II & $<40-160$ & $<40-320$ & $40-2560$ & $<40-320$ & $160-\geq 5120$ \\
\hline III & $<40$ & $<40$ & $<40$ & $<40$ & $<40-2560$ \\
\hline
\end{tabular}

particularly frequent in the period 1988 to 1990 , making up $36 \%$ of the isolates (Fig. 1). The corresponding value for 1988 alone was as high as $47 \%$ (not shown). The Danish isolate DK-5131 (Klapmølle) also showed this reaction pattern and was selected for further studies.

Isolates showing Reaction Pattern III were not neutralized at all by any of the 4 MAbs, and only moderately neutralized, or not neutralized at all, by the rabbit antiserum (median titre 640) (Table 2). Forty-eight of the isolates belonged to this group. Among them were the 6 isolates obtained from Prof. W. Ahne, including the isolate from turbot (Schlotfeldt et al. 1991) and the rainbow trout isolates $49 / 82 \& 67 / 82$ (Ahne et al. 1986). The Danish isolate DK-5151 (Rindsholm) was selected for further studies as a representative of this group. Seven of the 48 isolates belonging to Group III were not neutralized at all by the rabbit antiserum. By IF and ELISA, however, these isolates reacted with rabbit antiserum against VHSV Strain F1 and did not react with rabbit antiserum against IHNV (data not shown).

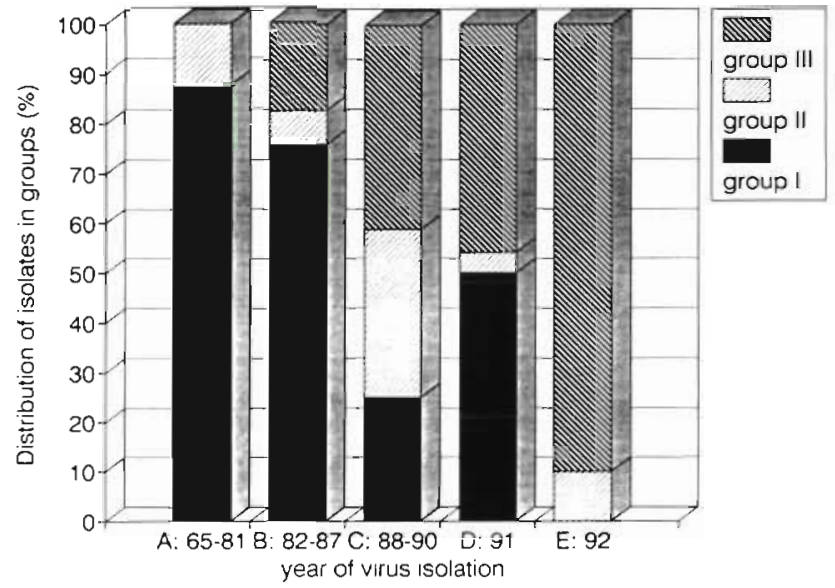

Fig. 1 Distribution by neutralization group of isolates from each of 5 periods from 1962 to 1992. Number of isolates in each period: was A, 8; B, 29; C, 56; D, 24; and E, 10
As shown in Fig. 1, the percentage of Danish isolates showing Reaction Pattern III appeared to be increasing in recent years and the pattern was not observed for any virus isolated before 1982. Conversely, the percentage of isolates showing Reaction Pattern I has been decreasing during the same period. Among isolates from VHS outbreaks in 1992, none belonged to Group I. The VHSV reference strain F1 was examined at cell-culture passage $10,99, \& 253$ following 0,1 or 3 clonings respectively. At all 3 passage levels Strain F1 showed the same neutralization pattern (I) with titres to all 5 antibodies ranging from 640 to 5120 . The individual values are shown in Table 3 .

\section{Immunoblotting}

Seven purified VHSV isolates representative of the 3 reaction patterns, i.e. Strain F1 and Strain He for Reaction Pattern I, Strains 23/75, DK-5131 \& DK-5276 for Reaction Pattern II and Strains DK-5151 \& DK-5422 for Reaction Pattern III were examined by immunoblotting. As shown on the colloidal gold stained membrane (Fig. 2a), the electrophoretic mobilities of the viral structural proteins $G, N, M_{1}$ and $M_{2}$ were very similar among all the isolates. In addition no differences were observed in the reactivity of the rabbit antiserum for the viral proteins of the 7 isolates (Fig. 2b).

Table 3. Plaque neutralization titres of 4 monoclonal antibodies (MAb) and 1 rabbit antiserum (PAb) against VHSV Strain F1 lested at 3 cell-culture passage levels

\begin{tabular}{|c|c|c|c|c|c|}
\hline \multirow{2}{*}{$\begin{array}{l}\text { Passage } \\
\text { number }\end{array}$} & \multicolumn{4}{|c|}{ MAb } & \multirow{2}{*}{$\begin{array}{c}\text { PAb } \\
\text { K697-2 }\end{array}$} \\
\hline & $3 \mathrm{~F} 1 \mathrm{H} 10$ & $3 F 2 D 4$ & $3 \mathrm{~F} 5 \mathrm{~A} 1$ & 3F3B4 & \\
\hline 10 & 2560 & 2560 & 2560 & 2560 & $\geq 5120$ \\
\hline 99 & 2560 & 1280 & 640 & 2560 & 2560 \\
\hline 253 & $\geq 5120$ & $\geq 5120$ & 2560 & 2560 & $\geq 5120$ \\
\hline
\end{tabular}


Fig. 2. Immunoblotting using rabbit antiserum K59 made against VHSV Strain F1 Membrane stained with either (a) colloidal gold or (b) immunostained with K59. Lanes 1: Strain F1 (Group I); Lanes 2: Strain 23/75 (Group II) Lanes 3: Strain DK-5422 (Group III); Lanes 4, Strain DK-5131 (Group II); Lanes 5, Strain DK5151 (Group III); Lanes 6, Strain He (Group I); Lanes 7, Strain DK-5276 (Group II)
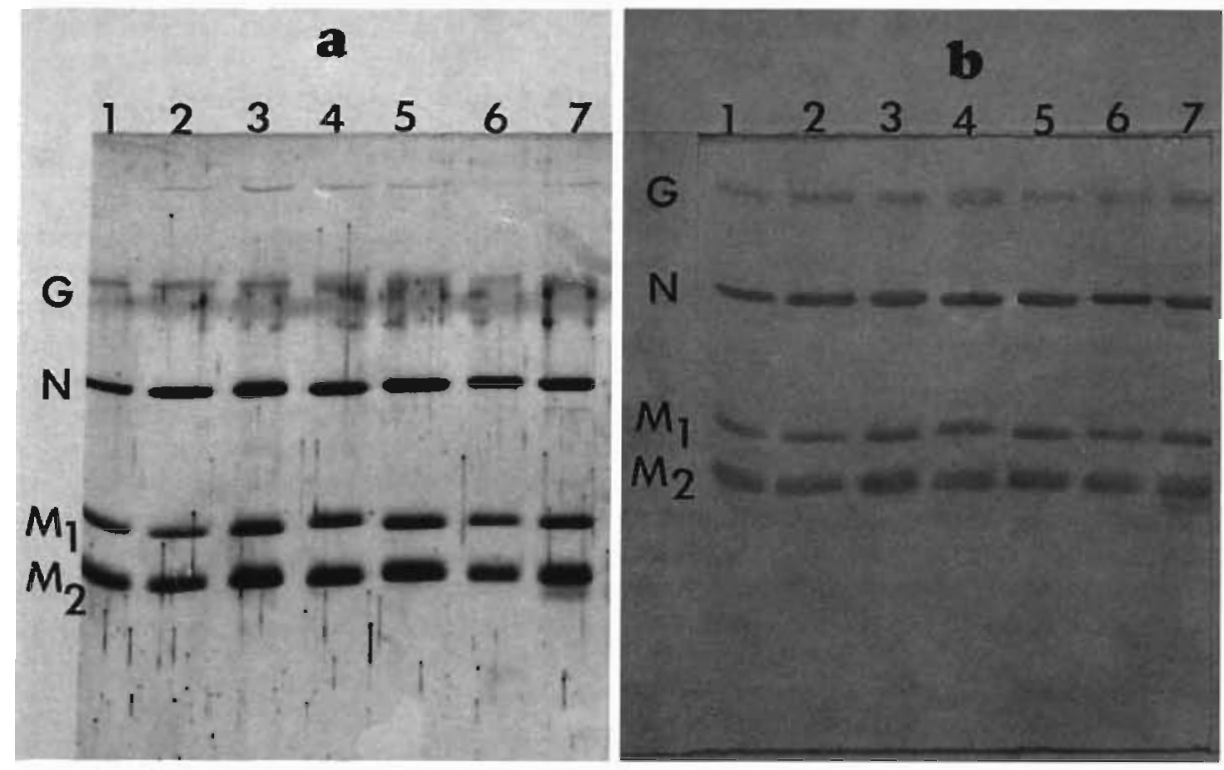

\section{Neutralization pattern of isolates from intercon- nected outbreaks of VHS}

Some of the 127 isolates used in this study originated from stocks of fish involved in simultaneous outbreaks of VHS at different trout farms on a single stream and were obtained on the same day or at intervals of a few days. An outbreak in one particular farm was represented by 5 isolates obtained on one day. Table 4 presents the results of the examination of 14 isolates representing the outbreaks in question, designated $A$ to E. All 5 isolates from Outbreaks A and B showed Reaction Pattern I, isolates from Outbreak C shared Reac- tion Pattern II, while isolates from Outbreaks D \& E showed Reaction Pattern III. In no cases were isolates representing different reaction patterns observed in connection with a single outbreak.

\section{DISCUSSION}

The use of noncloned virus isolates in this study was motivated by our goal of developing a technique for grouping fresh isolates of VHSV in an epidemiological context. Cloning represents selection of a certain subpopulation from a heterogeneous mixture and thus

Table 4. Plaque neutralization titres of 4 monoclonal antibodies (MAb) and 1 rabbit antiserum (PAb) to 14 virus isolates originating from 5 VHS outbreaks (A to $E$ )

\begin{tabular}{|c|c|c|c|c|c|c|c|c|c|}
\hline $\begin{array}{l}\text { VHS out- } \\
\text { break }\end{array}$ & $\begin{array}{c}\text { Isolate } \\
\text { no. }\end{array}$ & $\begin{array}{c}\text { Fish } \\
\text { farm no. }\end{array}$ & $\begin{array}{l}\text { Date of } \\
\text { isolation }\end{array}$ & $\begin{array}{c}\text { MAb } \\
\text { 3F1H10 }\end{array}$ & $\begin{array}{c}\text { MAb } \\
\text { 3F2D4 }\end{array}$ & $\begin{array}{c}\text { MAb } \\
3 \mathrm{~F} 5 \mathrm{~A} 1\end{array}$ & $\begin{array}{c}\text { MAb } \\
3 F 3 B 4\end{array}$ & $\begin{array}{c}\text { PAb } \\
\text { K697-2 }\end{array}$ & Group \\
\hline \multirow[t]{2}{*}{ A } & 3955 & 270104 & 25 May 87 & $\geq 5120$ & 2560 & $\geq 5120$ & $\geq 5120$ & 2560 & I \\
\hline & 3956 & 270105 & 25 May 87 & $\geq 5120$ & $\geq 5120$ & 2560 & $\geq 2560$ & 2560 & I \\
\hline \multirow[t]{3}{*}{ B } & 3957 & 130005 & 25 May 87 & $\geq 5120$ & 2560 & 2560 & $\geq 5120$ & 2560 & I \\
\hline & 3969 & 130007 & 2 Jun 87 & 2560 & 2560 & 2560 & 1280 & 2560 & I \\
\hline & 3970 & 130004 & 2 Jun 87 & 2560 & 2560 & 1280 & 1280 & 2560 & I \\
\hline \multirow[t]{2}{*}{$\mathrm{C}$} & 5122 & 280803 & 6 Apr 88 & 40 & $<40$ & 2560 & $<40$ & $\geq 5120$ & II \\
\hline & 5123 & 280804 & 6 Арг 88 & $<40$ & $<40$ & 1280 & $<40$ & $\geq 5120$ & II \\
\hline \multirow[t]{5}{*}{$\mathrm{D}$} & B-13 & 121658 & $9 \mathrm{Dec} 90$ & $<40$ & $<40$ & $<40$ & $<40$ & 1280 & IIl \\
\hline & B- -55 & 121658 & 9 Dec 90 & $<40$ & $<40$ & $<40$ & $<40$ & 1280 & III \\
\hline & B- 58 & 121658 & 9 Dec 90 & $<40$ & $<40$ & $<40$ & $<40$ & 1280 & III \\
\hline & B- 75 & 121658 & 9 Dec 90 & $<40$ & $<40$ & $<40$ & $<40$ & 640 & III \\
\hline & B- 80 & 121658 & 9 Dec 90 & $<40$ & $<40$ & $<40$ & $<40$ & 320 & III \\
\hline \multirow[t]{2}{*}{ E } & 5740 & 280804 & 11 Feb 90 & $<40$ & $<40$ & $<40$ & $<40$ & 40 & III \\
\hline & 5741 & 280803 & 11 Feb 90 & $<40$ & $<40$ & $<40$ & $<40$ & $<40$ & III \\
\hline
\end{tabular}


would be contraindicated in the present connection. Even using a cloned strain at 2 cell-culture passage levels the individual MAbs gave somewhat varying titres (Table 3). These variations, occasionally corresponding to 2 dilution steps, may reflect different ratios between infective and non-infective particles in the individual virus preparations rather than serological differences. As a consequence of this, and of the day to day variations observed, only titre differences representing 3 dilution steps or more were considered sig. nificant. The overall Leaction patterns, and thus the groupings of the isolates, normally were not influenced by these variations.

From results of the competitive ELISA, it is likely that the 4 neutralizing MAbs bind to the same or very closely related epitopes. No difference in relation to the Ig subclass was observed among the MAbs. MAb 3F5A1, however, was slightly different from the other 3 MAbs in that it inhibited their binding more efficiently than it was inhibited by them. This might be due to higher affinity or to a slightly different epitope specificity. Similarly the PNT analyses demonstrated that MAb 3F5A1 differed from the other MAbs by being able to neutralize more isolates. In fact, the same reaction patterns with the isolates might have been obtained if the panel had contained only the polyclonal rabbit serum, MAb 3F5A1 and a pool of the remaining 3 MAbs.

It was shown that PNT titres could be increased by lengthening the incubation period of the virus-antibody mixture from $1 \mathrm{~h}$ at $15^{\circ} \mathrm{C}$ to overnight at $15^{\circ} \mathrm{C}$ prior to inoculation; however, the overall reaction patterns of the individual isolates would not be changed as estimated by examination of 6 isolates (unpubl. results).

Three distinct reaction patterns were observed indicating the existence of 3 neutralization groups. Although a few isolates gave titres which were close to those of some isolates belonging to another group, most isolates were clearly separated. In that sense, the present grouping procedure represents a major improvement compared to the previous ones (Jørgensen 1972, 1974, Le Berre et al. 1977). However, one should bear in mind that the grouping might be different if other MAbs or more MAbs had been used, perhaps directed against different neutralizing epitopes. For that reason, the present grouping is likely to change with time and probably cannot be reproduced in other laboratories unless the same MAbs are used at the same concentrations. Preliminary results from the present study suggested the existence of 4 neutralization groups (Olesen et al. 1991b); however, further analysis showed that only 3 groups could be reproducibly distinguished, i.e. 2 of the 4 groups were pooled into 1.

Although clear antigenic differences between the virus isolates were detected by means of MAbs, it ap- peared that at least some neutralizing epitopes must be shared, since the rabbit antiserum against Strain Fl to some extent neutralized 120 out of 127 isolates tested. These results are in agreement with earlier findings (Jørgensen 1972) showing that 72 of 76 isolates were neutralized [log neutralization index (NI) above 4.0 ] by a rabbit antiserum to Strain $F 1$ with the remaining 4 yielding $\log \mathrm{NI}$ values between 1.3 and 2.0 , close to the borderline value of 1.7 commonly used to differentiate between significant and questionable neutralization. One of the latter strains, termed DK-61 and later He, was considered to represent a second neutralization type, i.e. 'Serotype' 2 . In the present study, that strain was neutralized as efficiently as the reference strain F1. This discrepancy may have been due to the different versions of the neutralization test used in the 2 studies, i.e. determination of NI and PNT respectively. These represent the 'constant serum, varying virus' and the 'constant virus, varying serum' methods, respectively (Casals 1967) and are likely to give results which are not directly comparable because the methods deal with different fractions of the virus population under study. PNT thus operates with about 30 to 70 infective virus particles per inoculum, whereas determination of NI operates with up to $10^{6}$ times more infective particles per inoculum. 'Neutralization variants' would have to occur with a higher frequency in a given virus suspension to be detectable by PNT than is necessary for detection by determination of NI. At the same time, PNT titres will be less influenced by the heterogeneity among virus populations. Strain 23/75, the previous 'Serotype' 3 reference strain, was found to be clearly different from strain F1 in the present study, a finding which may reflect the fact that it was originally characterized by means of plaque neutralization tests and not by determination of NI (Kinkelin \& Le Berre 1977).

A complete description of the serological relationship between viruses requires cross-neutralization tests using both homologous and heterologous antisera followed by calculation of $1 / \mathrm{r}$ values (Archetti \& Horsfall 1950). Due to the number of isolates in the present study as well as the difficulties in producing neutralizing antisera to VHSV (Jørgensen 1974) such an approach was impractical. However, on a limited scale, this approach has previously been followed with a few VHSV isolates. Thus cross-neutralization tests using homologous and heterologous antisera have shown close relationship between Strains F1 and He in one study (Jørgensen 1974), whereas in another (Le Berre et al. 1977) pronounced heterology among Strains $\mathrm{F} 1, \mathrm{He} \& 23 / 75$ was observed. These differences in results are probably due to differences in the properties of the antisera used, since identical neutralization techniques were used. This is not unlikely in 
view of the differences in cross-neutralization shown by individual antisera made against isolates of 2 other fish rhabdoviruses, spring viraemia of carp virus and pike fry rhabdovirus (Jørgensen et al. 1989).

The Group III isolates appear to represent a relatively new serological variant of VHSV. The first isolates in this group were from 2 VHS outbreaks in Germany in 1982, whereas the first Danish isolate was from an outbreak in 1986 . Isolates with this reaction pattern have become more common since then and were recovered from fish in 9 out of 10 new VHS outbreaks at facilities on 5 different river systems in 1992 . Although Group II isolates made up only 24 of the 127 isolates examined in the study, 15 of the 32 isolates from 1988 showed this reaction pattern. This is probably due to the fact that 8 of these 15 isolates originated from 2 water systems with several trout farms on each where fish may have been infected with VHSV from a common source. Apart from the example mentioned above, the mechanism driving the observed changes in frequency is not understood at present.

It remains to be seen how the non-neutralizable isolate 02/84 isolated by Dr de Kinkelin and recently described as 'Serotype' 4 of VHSV (Castric et al. 1992) fits into the present grouping system, since this isolate has not yet been made available. However, it appears likely that the isolate may belong to Group III.

Our Western blotting results using a polyclonal rabbit antiserum clearly indicated that the representative isolates from the 3 neutralization groups had common determinants on the G, N, M1 and M2 proteins. We did not observe the presence of electropherotype differences among the representative isolates of VHSV as described for IHN virus (Hsu et al. 1986). The very strong crossreactivity of the applied polyclonal rabbit antibodies with the 4 major structural proteins of the representative VHSV isolates in Western blotting in combination with the ability of such antibodies to neutralize 120 out of 127 examined isolates in our opinion show that the VHSV isolates are strongly related and make up one single serotype. We recommend that this serotype is referred to as Serotype 1 and that reference strain F1 is regarded as the type strain of this serotype. The 7 non-neutralized isolates represent neutralization variants. Previous distinction between 3 serotypes may have been based on insufficient data, in particular lack of data from Western blotting.

Although thus only 1 serotype was defined by means of polyclonal antibodies it appears that minor differences between isolates at the level of neutralization epitopes can be detected by means of neutralizing MAbs. These differences have enabled us to distinguish between 3 neutralization groups which have proved useful in epidemiological studies. We recommend the designation of these groups as Subtypes I to
III of Serotype 1 and stress that the subtypes are different from the previously described 'Serotypes' 1 to 3.

Although the present panel of reagents did not allow distinction between pathogenic and nonpathogenic strains or among isolates from different species of fish (e.g. brown trout isolates were present in neutralization Group I \& II, the eel isolate was in Group II and the turbot isolate was in Group III) the present grouping system has proved helpful in epidemiological studies, e.g. in tracing the source of infection of fish stocks (unpubl. results). Such studies in the future might be improved considerably if combined with the use of nucleic acid probe technology. In this regard, distinction between North American and European isolates of VHSV has been achieved using nucleic acid probes (Dr J. Winton pers. comm.). The typing system would also be improved by producing MAbs against additional VHSV isolates and including these in the panel. Since such reagents are already present in several laboratories, a cooperative effort towards further development of the grouping system is recommended.

\section{LITERATURE CITED}

Ahne, W., Jorgensen, P. E. V., Olesen, N. J., Schäfer, W., Stemhagen, P. (1986). Egtved virus: occurrence of strains not clearly identifiable by means of virus neutralization tests. J appl. Ichthyol. 2: 187-189

Archetti, I., Horsfall, F. L. (1950). Persistent antigenic variation of influenza A viruses after incomplete neutralization in vivo with heterologous immune serum. J. exp. Med. 92 $441-462$

Brunson, R., True, K., Yancey, J. (1989). VHS virus isolated at Makah national fish hatchery. Am. Fish. Soc., Fish Health Section, Newsl. 17: 3-4

Casals, J. (1967). Immunological techniques for animal viruses. In: Maramorosch, K., Koprowski, H. (eds.) Methods in virology, Vol. Ill. Academic Press, New York, p $201-241$

Castric, J., Jeffroy, J., Bearzotti, M., Kinkelin, P. de (1992). Isolation of viral haemorrhagic septicaemia virus (VHSV) from wild elvers Anguilla anguilla. Bull. Eur. Ass. Fish Pathol. 12: 21-23

Fijan, N., Sulimanovic, D., Bearzotti, M., Muzinic, D., Zwillenberg, L. O., Chilmonczyk, S., Vautherot, J. F., Kinkelin, P. de (1983). Some properties of the epithelioma papulosum cyprini (EPC) cell line from carp (Cyprinus carpio). Ann. Virol. (Annls Inst. Pasteur) 134 E: $207-220$

Hopper, K. (1989). The isolation of VHSV from chinook salmon at Glenwood Springs, Orcas Island, Washington. Am. Fish. Soc., Fish Health Section, Newsl. 17: 1-2

Hsu, Y.-L., Engelking, H. M., Leong, J. C. (1986). Occurrence of different types of infectious hematopoietic necrosis virus in tish. Appl. environ. Microbiol. 52: 1353-1361

Jensen, M. H. (1965). Research on the virus of Egtved disease Ann. N.Y Acad. Sci. 126: 422-426

Jensen, N. J., Bloch, B., Larsen, J. L. (1979). The ulcus syndrome in cod Gadus morhua. Nord. Vet-Med. 31: $436-442$

Jørgensen, P. E. V. (1972). Egtved virus: antigenic variation in 76 virus isolates examined in neutralization tests and by 
means of the fluorescent antibody technique. In: Mawdesley-Thomas, L. E. (ed.) Diseases of fish. Academic Press, London, p. 333-339

Jørgensen, P. E. V. (1974). A study of viral diseases in Danish rainbow trout. Their diagnosis and control. Ph.D thesis, Royal Veterinary and Agricultural University, Copenhagen

Jørgensen, P. E. V. (1980). Egtved virus: the susceptibility of brown trout and rainbow trout to eight virus isolates and the significance of the findings for the VHS control. In: Ahne, W. (ed.) Fish diseases. Springer-Verlag, Berlin, p. $3-7$

Jørgensen, P. E. V., Olesen, N. J. (1987). Cod ulcus syndrome rhabdovirus is indistinguishable from the Egtved (VHS) virus. Bull. Eur. Ass. Fish Pathol. 7: 73-74

Jørgensen, P. E. V., Olesen, N. J., Ahne, W., Lorenzen, N. (1989). SVCV and PFR viruses: serological examination of 22 isolates indicates close relationship between the two fish rhabdoviruses. In: Ahne, W., Kurstak, E. (eds.) Viruses of Iower vertebrates. Springer-Verlag, Berlin, p. 349-366

Kinkelin, P. de, Le Berre, M. (1977). Isolement d'un rhabdovirus pathogène de la truite fario Salmo trutta L.1766. C. r. Acad. Sci. Paris 284: 101-104

Le Berre, M., Kinkelin, P. de, Metzger, A. (1977). Identification sérologique des rhabdovirus des salmonidés. Bull. Off. int. Epiz. 87: 391-393

Lorenzen, N., Olesen, N. J., Jorgensen, P. E. V. (1988). Production and characterization of monoclonal antibodies to four Egtved virus structural proteins. Dis. aquat. Org. 4: $35-42$

Lorenzen, N., Olesen, N. J., Jørgensen, P. E. V. (1990). Neutralization of Egtved virus pathogenicity to cell cultures and in fish by monoclonal antibodies to the viral Gprotein. J. gen. Virol. 71: 561-567

McAllister, P. E., Wagner, R. R. (1975). Structural proteins of two salmonid rhabdoviruses. J. Virol. 15: 733-738

Meier, W., Jørgensen, P. E. V. (1980). Isolation of VHS virus

This article was presented by F. M. Hetrick, College Park, Maryland, USA from pike fry Esox lucius with haemorrhagic symptoms In: A.hne, W. (ed.) Fish diseases. Springer Verlag, Berlin, $p$ $8-17$

Moremans, M., Daniels, G., May, J. de (1985). Sensitive colloidal metal (gold or silver) staining of protein blots on nitrocellulose membranes. Analyt. Biochem. 145 $315-321$

Olesen, N. J., Jørgensen, P. E. V. (1986). Detection of neutralizing antibody to Egtved virus in rainbow trout Salmo gairdneri by plaque neutralization test with complement addition. J appl. Ichthyol. 2: 33-41

Olesen, N. J., Jørgensen, P. E. V. (1991). Rapid detection of viral haemorrhagic septicaemia virus in fish by ELISA. J. appl. Ichthyol. 7: 183-186

Olesen, N. J., Lorenzen, N., Jørgensen, P. E. V. (1991a) Detection of rainbow trout antibody to Egtved virus by enzyme-linked immunosorbent assay (ELISA), immunofluorescence (IF), and plaque neutralization tests ( $50 \%$ PNT). Dis. aquat. Org. 10: $31-38$

Olesen, N. J., Lorenzen, N., Jørgensen, P. E. V. (1991b). Serological differentiation of Egtved virus (VHSV) using neutralizing monoclonal and polyclonal antibodies. Abstract 79. 5th int. Conf. Eur. Assoc. Fish Pathol. on Diseases of Fish and Shellfish, Budapest.

Sanz, F. A., Coll, J. M. (1992). Detection of hemorrhagic septicemia virus of salmonid fishes by use of an enzyme-linked immunosorbent assay containing high sodium chloride concentration and two noncompetitive monoclonal antibodies against early viral nucleoproteins. Am. J. Vet. Res. 53: $897-903$

Schlotfeldt, H. J., Ahne, W., Jørgensen, P. E. V., Glende, W. (1991). Occurrence of viral haemorrhagic septicaemia in turbot Scophthalmus maximus - a natural outbreak. Bull Eur. Ass. Fish Pathol. 11: 105-107

Wolf, K., Gravell, M., Malsberger, R. G. (1966). Lymphocystis virus: isolation and propagation in centrarchid fish cell lines. Science 151: 1004-1005

Manuscript first received: December 15, 1992

Revised version accepted: May 24, 1993 